\title{
PAPÁGl:" Határon átnyúló világörökségi helyszínekhez kapcsolódó kérdések
}

\begin{abstract}
The foundation of the UNESCO's World Heritage Program was guided by the principle to create an international cooperation that is able to preserve the cultural and natural values of outstanding importance for humankind. Meeting the requirements of the World Heritage Convention 8 Hungarian sites have been inscribed on the List. However, since cultures do not adjust to political borders, several World Heritage Sites span over the borders. Out of the 8 Hungarian World Heritage Sites 2 extends to the territory of the neighbouring countries, which means that they had to be submitted for the List jointly. Due to the particular state of these World Heritage Sites, a particular situation evolves in the operation of the Heritage Sites. Since the countries own the sites jointly, they need to harmonise their activities in favour of the effective maintenance of these heritage sites. The study deals with the above mentioned territories' problems and their possible solutions.
\end{abstract}

\section{Bevezetés}

Az UNESCO Világörökségi Program létrehozásakor az a cél vezérelte a megalakulást, hogy egy nemzetek felett álló, politikai határokon átívelő egyuittmüködést jöjjön létre, amely képes az emberiség számára kiemelkedő értékekkel bíró kulturális és természeti örökségek megóvására. A Világörökségi Egyezmény keretein belül az arra érdemesnek tartott helyszínek a Világörökségi Listára kerülnek.

Habár a Világörökségi Lista nem a turizmus érdekeit kívánja kiszolgálni, a Világörökségi címkének köszönhetően a Listára került helyszínek nagyobb ismertségre tesznek szert, és jobban bekerülnek a köztudatba (Pap-Boros-Pál 2009). Ebből kifolyólag az egyediséget és értéket biztosító világörökségi címke az utazók egyik biztos védjegyévé is válik, és a turizmusban résztvevők előszeretettel keresik fel a világörökségi helyszíneket (Boros-Garamhegyi 2009). Az egyes világörökségi helyszínek iránt megnövekedett turisztikai kereslet pedig hatással van mind az örökségi helyszínek mind a környező települések gazdaságában és társadalmában lejátszódó folyamatokra (Puczkó- átz 2002, Csordás 2008).

\section{Korábbi kutatások és felmerülö nehézségek}

A korábbiakban kísérletet tettünk a világörökségi helyszínek és 20 kilométeres környezetük turizmusában történt változások vizsgálatára (Pap 2008). Ekkor a KSH statisztikai adatait felhasználva kimutathatóvá vált a helyszínek turizmusának növekedése. A kutatás során minden helyszín esetén a világörökséggé válás évét jellemző turisztikai mutatókat hasonlítottuk össze a 2004-es bázisév turisztikai mutatóival, és megfigyeltük a változások mértékét. Azonban már a 3 vizsgált magyarországi helyszín: Pannonhalma, Hollókő és Hortobágy esetében számos probléma merüilt fel a kutatás során.

Első sorban az 1998-as IKIM-rendelet (IKIM 1998) jelentett némi nehézséget, amelynek köszönhetően megváltozott a szálláshely kategóriák korábban alkalmazott statisztikai

\footnotetext{
* Tanársegéd - Szegedi Tudományegyetem Gazdaság- és Társadalomföldrajz Tanszék.
} 
kategorizálása. Ebböl kifolyólag az olyan világörökségi helyszínek esetén, amelyek még 1998 előtt kerültek a listára elengedhetetlen a megváltozott kategóriák egymással való harmonizálása.

További nehézséget jelentett, ha a vizsgált térségben a világörökségi helyszíneken kívül más jelentős idegenforgalmi attrakcióval rendelkező település is volt a térségben, hiszen ebben az esetben az elvonhatja a világörökségi helyszín szálláshelyeinek szállóvendégeit (pl. Hortobágy - 1. ábra). Ez természetesen nem jelenti azt, hogy a világörökségi helyszínt kevesebb látogató keresné fel, mindössze annyi a változás, hogy az időközben kiépült szálláshely-kapacitás és az attrakciók kiszélesedett köre elvonja a térség addigi szálláshelyit igénybevevő vendégek egy részét.

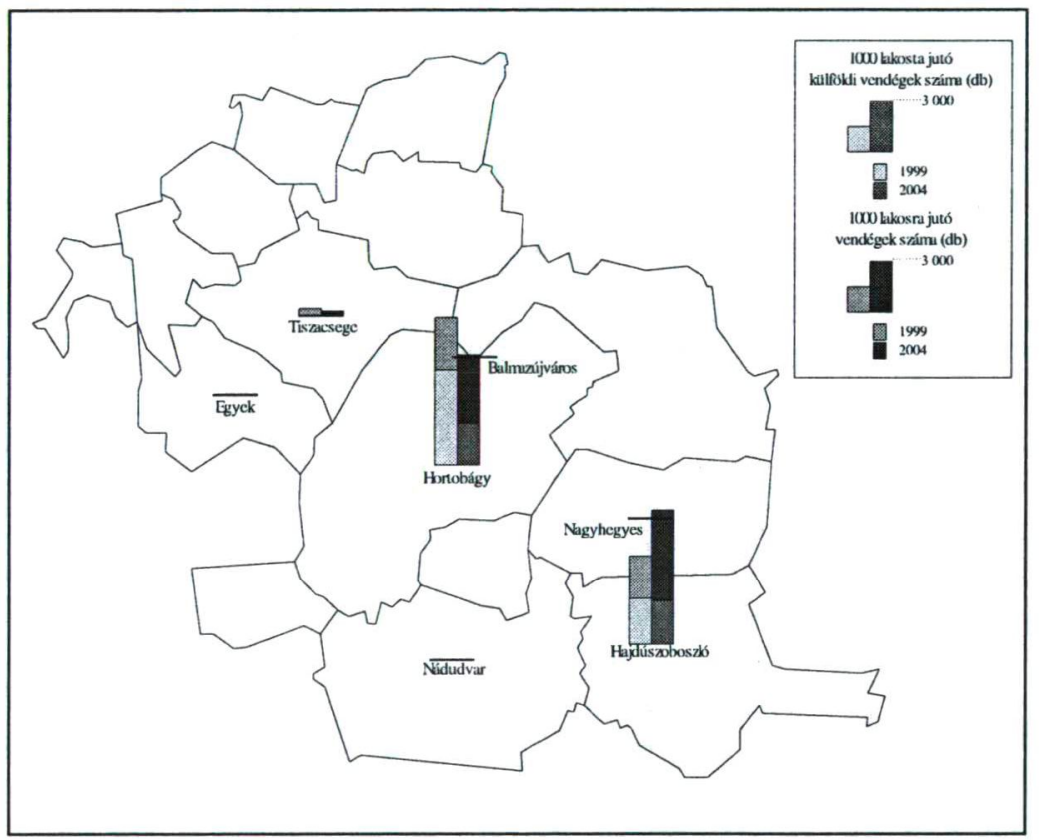

1. ábra. 1000 lakosra jutó összes és külföldi vendégek száma a kereskedelmi szálláshelyeken 1999-ben és 2004-ben (Hortobágyon és a környező településeken)

(Forrás: KSH T-STAR, a szerző szerkesztése, 2006)

Az eddig még nem vizsgált világörökségi helyszínek esetén, azonban e két nehézség mellett számos egyébbel is szembe kell nézni.

Kultúrtájak vagy természeti örökségek esetén nem egy településre korlátozódik a világörökség, hanem több településre is kiterjed. Ebben az esetben a 20 km-es sugarú környék meghatározása sem olyan egyértelmü és a vizsgálandó terület mérete is jelentősen megnövekedhet.

További nehézséget jelent a turizmus intenzitásának mérése olyan természeti értékekkel rendelkezö, de szigorú természetvédelmi eljárás alatt lévő területek esetén, amelyek védettségükből adódóan nem teljes egészében látogathatók. Általában a szigorú védelem alatt álló területeken szálláshelyet sem lehet igénybe venni, ami nagymértékben megnehezíti a turisták érdeklődésének statisztikai számszerüsítésének lehetőségét. Ez esetben a térségben lévő kiállítóházak és múzeumok elkelt belépőjegyeinek számából lehet következtetni a látogatottság intenzitásának változására. 


\section{A turizmus intenzitásának mérési korlátja}

Európai és országai elökelő helyet foglalnak el a világ idegenforgalmi keresletét illetően, hiszen a nemzetközi turistaérkezések $53,1 \%$-a és a nemzetközi turistaforgalomból származó bevételek 50,2\%-a erre a makrorégióra tehetö (WTO 2009). Ausztria, Szlovákia és Magyarország azonban eltérő módon veszik ki részüket az európai turizmus forgalmából (1. táblázat).

1. táblázat. Ausztria, Magyarország és Szlovákia részesedése Európa turistaforgalmából, 2005

\begin{tabular}{|l|c|c|c|c|}
\hline & $\begin{array}{c}\text { Nemzetközi turis- } \\
\text { taérkezések } \\
\text { száma (1000 fó) }\end{array}$ & $\begin{array}{c}\text { Nemzetközi turis- } \\
\text { taérkezések ará- } \\
\text { nya (\%) }\end{array}$ & $\begin{array}{c}\text { A nemzetközi } \\
\text { turistaérkezésból } \\
\text { származó jövede- } \\
\text { lem (millió euró) }\end{array}$ & $\begin{array}{c}\text { A nemzetközi } \\
\text { turistaérkezésból } \\
\text { származó jövede- } \\
\text { lem aránya (\%) }\end{array}$ \\
\hline Ausztria & 19952 & 4,5 & 2432 & 4,4 \\
\hline Magyarország & 10048 & 2,3 & 3433 & 1,2 \\
\hline Szlovákia & 1515 & 0,3 & 972 & 0,3 \\
\hline Európa & 441528 & 100 & 279931 & 100 \\
\hline
\end{tabular}

Forrás: WTO

Viszont amennyiben nem a teljes országra vonatkozó idegenforgalmi teljesítményt szeretnénk felmérni, hanem egy-egy kisebb tájegység vagy vidék idegenforgalmi szerepét az adott országon vagy Európán beliil, számos nehézég nehezíti a kutatást. A legnagyobb problémát az jelenti, hogy a Turisztikai Világszervezet és az Európai Unió statisztikai adatbázisa is csak országos szinten gyüjti az erre vonatkozó statisztikai adatokat. Kisebb léptékü terület esetén az országos adatszolgáltatók jelenthetnek megoldást. Azonban ha a vizsgálandó terület politikai határokon is átnyúlik, a felmerülő akadályok az eltérő statisztikai adatok gyüjtéséböl, az egyes statisztikai kategóriák eltérő csoportosításából adódóan igencsak megnehezítik a szükséges adatok összehangolását.

Ilyen nehézségekkel kell megküzdeni a 8 magyarországi világörökségi helyszínből 2 esetén, amelyeket a szomszédos országokkal közösen terjesztettek fel a világörökségi listára.

Az Aggteleki-karszt és a Szlovák-karszt barlangjai az egyedülállóan gazdag karsztos felszíni illetve felszín alatti formáknak köszönhetően vált világörökséggé. Az 56562 hektárnyi világörökségi terület 64,9\%-a Szlovákia területére, 35,1\% pedig Magyarország területére esik (WHC Nomination Documentation).

1995-ben az Európa legnagyobb szikes tavaként emlegetett Fertőtó (Neusidlersee) kultúrtáj is a világörökség részévé lett. Az 68369 hektár nagyságú terület Magyarország és Ausztria közös felterjesztése révén került a listára. A terület nagyobbik része $(76,8 \%)$ a határon túl, kisebbik része $(23,2 \%)$ pedig a határon innen található. A világörökségi területen lévő 21 telepuilésből 13 Ausztriában, 8 pedig Magyarországon található (World Heritage Cultural Ladscape Fertő/Neusidlersee Management Plan).

A vizsgálandó területet kettészelő határvonal nehézséget jelent mind az adatgyüjtést, mind az egységes kezelést illetően. A legmegbízhatóbb adatforrásnak az Európai Unió statisztikai adatbázisa számítana, hiszen egységesen kezelt és egységes módon értelmezett adatokat tartalmaz, ami alapvető fontosságú az összehasonlíthatóság szempontjából. Azonban az Európai Unió adatgyüjtése során felhasznált statisztikai szintek a 3 ország esetében nem azonosan alakulnak (2. táblázat). Például Szlovákia esetében a NUTS 0 szint üresen marad, és így az összes többi kategória esetén is egy szinttel eltolódnak az értékek. $\mathrm{Az}$ ebböl következő adat-harmonizáció azonban még viszonylag könnyen megoldható. Ettől nagyobb gondot jelent, hogy a legtöbb adat csak a NUTS 0 vagy NUTS 1-es szinten 
lelhető fel. A turizmusra vonatkozóan NUTS 2-es szinten mindössze 2 turisztikai mutató (a vendégéjszakák száma és a szálláshelyet igénybevevők száma) áll a rendelkezésre. A LAU 1 és a LAU 2-es szinteken semmilyen statisztikai adat nem lelhető fel, pedig a kisléptékü területi vizsgálódások esetén ez jelentene megoldást.

\section{2. táblázat. Az Európai Unió földrajzi kódolási rendszere Magyarország, Ausztria és Szlovákia esetében}

\begin{tabular}{|c|c|c|c|}
\hline & Magyarország & Ausztria & Szlovákia \\
\hline NUTS 0 & $\begin{array}{c}1 \\
\text { (az ország) }\end{array}$ & $\begin{array}{c}1 \\
\text { (az ország) }\end{array}$ & - \\
\hline NUTS 1 & $\begin{array}{c}3 \\
\text { (nagyrégiók) }\end{array}$ & $\begin{array}{c}3 \\
\text { (több szövetségi tartomány) }\end{array}$ & $\begin{array}{c}1 \\
\text { (az ország) }\end{array}$ \\
\hline NUTS 2 & $\begin{array}{c}\mathbf{9} \\
\text { (tervezési-statisztikai régiók) }\end{array}$ & $\begin{array}{c}\mathbf{3} \\
\text { (szövetségi tartományok) }\end{array}$ & (körzetek csoportjai) \\
\hline NUTS 3 & $\begin{array}{c}\mathbf{2 0} \\
\text { (megyék + Bp.) }\end{array}$ & $\begin{array}{c}35 \\
\text { (körzetek csoportjai) }\end{array}$ & (körzetek - kraje) \\
\hline LAU 1 & 174 & 35 & 79 \\
\hline LAU 2 & 3152 & 2357 & 2928 \\
\hline
\end{tabular}

Forrás: http://ec.europa.eu/eurostat/ramon/nuts/basicnuts_regions_en.html

\section{Eltérö kezelési módok a határ két oldalán}

A területeket átszelő határvonalak nem csak az adatgyüjtésben jelenthetnek problémát. A határ két oldalán megvalósuló eltérö kezelési módozatok és az ebböl származó, gyakran nehézségektöl sem mentes helyzetek is rejthetnek magukban némi problémát.

A Fertő tavi kultúrtáj esetében erös az együttmüködés a terület közös kezelését illetöen. $\mathrm{Az}$ ausztriai oldalon a kultúrtáj Burgenland régió részét képezi. Az ausztriai utazásokat leginkább motiváló tényezők (a hegyvidék és a síközpontok) nem jellemzöek erre a régióra. Ehelyett a pannon-jellegü, hazánkat idézö táj jelenik itt meg, amely leginkább a városi lakosság kikapcsolódását teszi lehetővé - elsősorban a kerékpáros turizmus, illetve a falusi turizmus keretin belül. Maga a térség ausztriai idegenforgalmi régiói közül az egyik legkisebb, és a vendégéjszakák számát tekintve is itt mutatható ki a legalacsonyabb érték (Gyuricza 2008). Ameddig a határ túloldalán a Fertő tó nagyobbik és nyílt víztükörrel rendelkező része található, addig Magyarországra a sekélyebb és sürủ növényzettel rendelkezö része esik, amely kitünő feltételeket nyújt a madárrezervátumok fenntartására. A FertöHanság Nemzeti Park egyes területei, melyek egyben világörökségi területek is, a Ramsariegyezmény értelmében kiemelten védett vizes térséggé váltak, és ezeken a területeken a vízimadarak védelme az elsődleges szempont. Ebböl kifolyólag a közelben lévő olyan tóparti területek, amelyeket föként fürdözés vagy strandolás céljából keresnek fel a látogatók, zavarhatják az élővilág nyugodt életkörülményeit.

Az Aggteleki karszt esetében is megemlíthető néhány példa az egységes természetföldrajzi terület eltérỏ kezelését illetỏen. Magyarországon a karsztfelszínen kialakult sérülékeny talaj megvédése érdekében tarlóégetést végeznek a térség szántóföldjein. A határ túloldalán azonban arra is van példa, hogy a különböző mezőgazdasági munkákat nehéz munkagépekkel végzik el. Vagy további példaként említhető meg, hogy amíg hazánkban a védett növények megóvása érdekében évente mindössze kettöre korlátozták a kaszálások számát, addig a határ túl oldalán gyakrabban (évente akár négyszer is) sor kerülhet a kaszálásra.

Habár sajnálatos módon a természetvédelmi intézkedéseket még nem sikerült össze- 
hangolni a határ két oldalán, a kulturális együttmüködés szép példája a Gömör-Tornai Fesztivál, amely a határ két oldalán mintegy húsz település bekapcsolódásával történő, többnapos, már kilenc éve folyamatosan megrendezésre kerülö rendezvénysorozat.

\section{5. Összegzés}

A nyolc magyarországi világörökségi helyszín közül az Aggteleki-karszt és a Szlovákkarszt barlangjai, valamint a Fertő kultúrtáj olyan világörökségi helyszínek, amelyek a szomszédos országokkal közösen kerültek felterjesztésre. Mindkét terület természetföldrajzilag egységes területet képez, azonban a területeket átszegö politikai határvonalak megnehezítik a területre vonatkozó adatgyüjtést és eltérő kezelési módot eredményezhetnek a határ két oldalán.

A nehézségek elöidézői közé sorolható a határ két oldalán lévő eltérő felépítésü és müködésü intézményi rendszer, a világörökségi helyszínek kezelő testületeinek, illetve kezelési terveinek hiánya, és a világörökségi területek nem egyértelmủ szabályozása a magterületeken és a puffer területeken elvégezendö feladatok tekintetében. Habár a világörökségi helyszínek fenntartása állami kötelesség lenne, az állam nem rendelkezik elegendő forrással e célok megvalósítására.

Az összehangolt kezelés érdekében kiemelkedő fontosságú lenne a kezelö testületek feladatkörének és jogainak egyértelmü rögzítése, illetve a kezelési tervek közös kidolgozása.

A statisztikai adatok egységesített gyüjtése érdekében a legideálisabb megoldást az jelentené, ha az Európai Unió statisztikai hivatala összegyüjtené a tagországok által önállóan gyüjtött kistérségi (LAU 1) és településszintü (LAU 2) adatait is, ezeket központilag öszszehangolná és egy egységes adatbázisban tenné hozzáférhetövé. Másik megoldás lenne a világörökségi területek esetén, ha maga az UNESCO szabályozná és tenné kötelezővé a világörökségi helyszínek területén az adatgyüjtést. Az ilyen módon összegyüjtött adatok a területi folyamatok nyomon kísérése során, illetve a fejlesztések megtervezésekor is segítséget nyújthatnának.

\section{Irodalomjegyzék}

Boros L.-Garamhegyi Á. (2009): Bevezetés a településmarketingbe. Jatepress. Szeged, p. 170.

Csordás L. (2008): Spatial spread and the development of tourism. Motivations of the foreign visitors in the border regions of the northeast Great Hungarian Plain. In: Süli-Zakar I. (ed.) Neighbours and Patterns: On the two sides of the border. Debrecen. Magyarország, pp. 315-322.

Gyuricza L. (2008): A turizmus nemzetközi földrajza. Dialóg Campus. Budapest-Pécs. 123 p.

IKIM (1998): 45/1998. (VI. 24.) IKIM rendelet a kereskedelmi és a fizetövendéglátó szálláshelyek osztályba sorolásáról, valamint a falusi szálláshelyek minősítéséröl.

Pap Á. (2008): Az élénk turisztikai kereslet hatása a települések gazdasági kömyezetére egy magyar világörökség példáján. II. terület- és vidékfejlesztési konferencia, Kaposvár, 2008. április 25. pp. 44-48.

Pap Á-Boros L-Pál V. (2009): World Heritage - Tourism - Globalistaion. In Sustainable Mountain Tourism - Local Responses for Global Changes. The second International Tourism Conference, EdituraUniversitaria, Craiova. pp. 221-228.

Puczkó L.-Rátz T. (2002): A turizmus hatásai. Aula, Budapest.

World Heritage Cultural Ladscape Fertö/Neusidlersee Management Plan, Vienna, Budapest, Eisenstadt, Fertőd 2003. p. 154. (elérhetö:http://whc.unesco.org/en/list/772/documents/)

WHC Nomnination Documentation - Caves of the Aggtelek Karst and Slovak Karst 2000. (elérhetö: http://whc.unesco.org/en/list/725/documents/)

WTO 2009 Tourism Highlights (elérhető: http://www.unwto.org/facts/eng/highlights.htm)

http://ec.europa.eu/eurostat/ramon/nuts/basicnuts_regions_en.html 